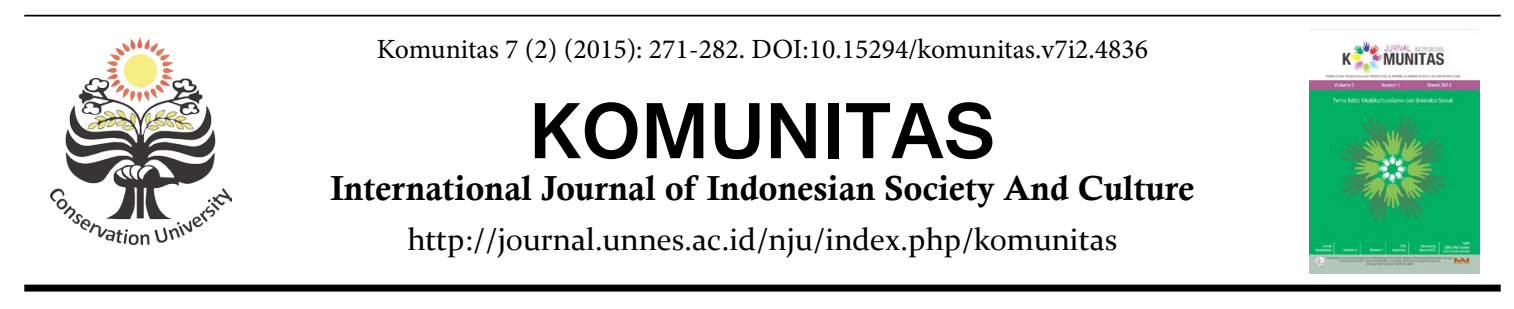

\title{
The Information Needs and Media of Small Islands Society
}

\author{
Ambar Yoganingrum ${ }^{1 凶}$, Wahyoe S Hantoro \\ ${ }^{1}$ Centre for Documentation and Scientific Information - Indonesian Institute of Sciences \\ ${ }^{2}$ Geotechnology Research Center. Indonesian Institute of Sciences
}

Permalink/DOI: http://dx.doi.org/10.15294/komunitas.v7i2.4836

Received : August 2015; Accepted: September 2015; Published: September 2015

\begin{abstract}
The purpose of the study is to identify the needs and appropriate media for information services regarding the management of freshwater and sanitation of small island community in North Lombok. The data was collected using a questionnaire with the households as respondents. The study then compared two samples i.e. the community in the district of Lombok north and Kepulauan Seribu using Kolmogorov-Smirnov technique. The community in both districts has similarities and differences in the aspect of demographic, understanding, behaviors as well as the information needs and the preferred media. The study concludes that the community in Lombok Utara needs information about global warming and its effect to the damage of freshwater and sanitation. The media information such as film animation is necessary to be considered due to fact that people of the two districts have a longer time on the land.
\end{abstract}

Keywords: information needs; information media; fresh water management; small islands

\section{INTRODUCTION}

Coral reefs, mangroves, coastal forests and rock cliffs are natural protectors against the dangers of extreme events due to climate dynamics, e.g. strong waves (Hantoro et al. 2013; Hantoro et al. 2014). However, society is driven by the needs of building materials so they make them as economic resources, causing the damage to the natural protectors. The damage to the natural protective layer will cause the destruction of fresh water in that area. The condition is worsened by the negative behavior, such as allowing the flow of fresh water into the sea, therefore reducing the balance of freshwater in coastal area or small island and building latrines and disposing the waste into any place on the coastal areas and waters, resulting in pollution for ground water and coastal environments (Hantoro et al. 2008a; Hantoro et al. 2008b).

Limitation in accessing the informa- tion has caused the community unable to have the capability of disaster mitigation and adaptability to the impacts of global warming (Gentle and Maraseni, 2012; Bryana et al. 2009). Therefore, the concepts and models related to information services need to be proposed to improve disaster mitigation capabilities and adaptability. Indonesia's information services for people in the vulnerable regions to climate dynamics have not been developed in an organized way. Therefore, this study aims to identify the demographic data, understanding, behavior, and media information selected by the small islands community in Gili Indah village, North Lombok regency. This study is also to test the equality of two samples which are communities in North Lombok district and Kepulauan Seribu district with the assumption that people in the two districts have similarities in demographic aspect, understanding of global warming, behavior 
and selected information media. Hence, it is expected to obtain a more complete picture of the development model of freshwater management information services in order to improve the adaptation of small island communities in Indonesia.

Information services to coastal communities and small islands are carried out with the aim to increase the mitigation capabilities and adaptability of community groups. Socialization of climate change on farmers and fishermen in five districts of Indramayu, North Jakarta, Batu, Serdang Bedagai, and Bau-Bau districts are done using radio media (Abdurrahin 2012). Based on research of Hidayati (2012), socialization in five districts/cities are not optimal due to the limited number of fishermen and farmers who listen to the radio broadcast as well as the broadcasting content. Problems encountered by fishermen and farmers in each district/city are diverse and complex, requiring precision in the selection of the information broadcast content.

According to Zach and McKnight (2010), information professionals are less improvised in meeting the information needs of the victims of disasters caused by natural or man-made. They should be able to create new, more effective services to meet the diverse information needs, during and immediately after the disaster. Zach and McKnight (2010) propose the use of educational modules that contain examples of best practices in information services. Information professionals are expected to develop strategies to respond to the information needs of users who often change with reference to the module.

Shepard and Shaw (2007) use threedimensional visualization tools which describe the conditions that will occur. The tool is used to raise awareness and encourage community involvement related to environmental issues. Conceptually, the tool is able to integrate the impact, adaptation, and $\mathrm{mi}-$ tigation in a holistic plausible scenario and examine the social impact or obstacles in the implementation of the new policy. Therefore, it will speed up the completion of the problems related to climate dynamics. Like- wise, Baldwin et al. (2012) uses a visualization tool as well as a participatory approach to the interpretation and communication of scientific knowledge to help understanding the groundwater hydrology for communities and local government. This collaborative and participatory ways as well as visual method are able to increase the understanding of the issue of natural resource management. Such a tool could help addressing the security threats of land due to climate dynamics and pressures due to the use of continuous agriculture and mining activities.

Small islands in Indonesia are formed by various geological processes, creating the islands with diverse landscapes and rocks (Hantoro 2010). Landscape and geology of islands create coastal regions in the form of sloping plains or steep cliffs, wide or narrow with the types of plants that also vary according to the growing abilities. Gili Trawangan, Gili Meno and Gili Air in North Lombok regency are islands which are actually parts of the outcrop alluvium volcano forming the mainland. In the northern part of Gili Trawangan, it is covered by alluvium. In the coastal part of the island is covered by limestone of shell reef building organisms. This material is believed to be the remaining of limestone reefs from the Holocene age at an altitude of up to $1 \mathrm{~m}$ above sea level, which is commonly found in the small island beach. Gili Meno and Gili Air which are in the form of sloping land, have no outcrop of volcanic rocks as in Gili Trawangan. The surface of the island is in the form of deposition of alluvium and rocks tuffs and fragments of limestone reefs materials.

Rainwater in the three Gili/islands is largely permeated by the alluvial layer and partly restrained by the top of the calcareous tufa rock. This infiltration forms a layer which is saturated with the water in the shallow aquifer. In the hills with outcrops of calcareous tufa, water is seeped to a depth of more than $15 \mathrm{~m}$. In the building area, the water flows as surface flow, through channels and is finally thrown into the sea.

The area of Kepulauan Seribu in Jakarta consists of ramps and small islands, an 
island reef with a height of not more than 2 $\mathrm{m}$ above sea level. As an island of coral reefs, the islands' cover layer materials are sand and carbonate crusts material fragments of coral reefs. The cover layer thickness ranges from a few centimeters up to approximately $2 \mathrm{~m}$. Most coastal mangrove island has a cover with a thickness from a few meters to more than $50 \mathrm{~m}$ (Hantoro 2010).

Freshwater found in Kepulauan Seribu region only comes from rain water. Water is absorbed and stored in weathering layers of carbonate material. Under the saturated fresh water layer, there is a layer of coarse sediment which is filled with salty sea water. Excessive intake of fresh water causes sediment pore void is then filled by saltwater from the below. The charging through the seepage of rain water runs into trouble because the larger type of salt water from the rain. Charging back can only be done with the injection of fresh water through pipes connected from the fresh water reservoir at a certain height, into a layer that has been filled with salt water (Hantoro et al. 2008b). Hydrostatic pressure helps repelling saltwater from freshwater. How to fill a layer that has been filled with salt water injection is an easy and inexpensive way in an attempt to restore the content of the fresh water on a small island in Kepulauan Seribu and Gili Trawangan which both have a layer of sand, but a different way of formation.

\section{RESEARCH METHODS}

This research was conducted in December 2010 - April 2011 in North Lombok regency. The district has three small islands, namely Gili Trawangan, Gili Air and Gili Meno, where all three islands belong to the territory of the village of Gili Indah. A total of 65 semi-open questionnaires were distributed to the respondents, namely the households in those three islands. The sampling used proportional sampling technique, so that by comparing the number of households the 25 questionnaires were distributed to Gili Trawangan, Gili Air 29 and 11 to Gili Meno. Determination of households who became respondents was randomized. The questionnaire had to be read out to a number of respondents, because most of them cannot read. A number of respondents who could read requested the questionnaires to be read because they did not have the confidence to fill in. The survey results were analyzed using simple statistics that measured the percentage. Besides, the observation in the environment of the island was conducted as well.

The study also examined the similarity of two samples, namely small island communities in North Lombok district and the Kepulauan Seribu by using the techniques of Kolmogorov-Smirnov. The hypothesis in this test was the demographic data, as well as the understanding of the public information media selection was the same in both districts. If the probability value was greater than 0.05 (Ho> 0.05) then the hypothesis was accepted, if it was smaller than 0.05 (Ho $<0.05)$ then it was rejected. Data from the Kepulauan Seribu district used research results of Yoganingrum et al (2012).

\section{RESULTS AND DISCUSSION}

Gili Indah is the only village in the area of North Lombok district located in the small island. The village consists of three small islands of Gili Trawangan, Gili Air and Gili Meno. The village head office is located in Gili Air. These three islands of Gili Trawangan are mainly foreign tourists' destination.

Three islands are accessible by public transportation in a form of single-engine boat for about 30 minutes from the island of Lombok. The regular transportation is operated approximately 3-4 times a day. Three Gilis are also accessible from the island approximately of 1-1.5 hours by speed boat, which is managed by the private sector. There is also a large vessel that connects Bali and Lombok islands which takes about 4 hours. Lombok Island also has an international airport. Given the three islands are tourist destinations, the majority of the people in the three Gilis' livelihood is as a self-employed, which relates to the provision of facilities for tourists such as accommodation, shops, grocery stores, cidomo driver and so on, with the average income of the population up to 5 million a month (Table 1). Not a few tourists 
Table 1. Demographic and fresh water sources of residents

\begin{tabular}{|c|c|c|c|c|c|}
\hline Occupation & $\begin{array}{l}\text { Gili } \\
\text { Air }\end{array}$ & $\begin{array}{l}\text { Gili } \\
\text { Memo }\end{array}$ & $\begin{array}{c}\text { Gilir } \\
\text { Trawangan } \\
\end{array}$ & people & Percentage \\
\hline fisherman & 4 & 4 & $\overline{\mathrm{o}}$ & 8 & $12 \%$ \\
\hline $\begin{array}{l}\text { Staff/PNS/Policemen, and military } \\
\text { troop }\end{array}$ & 6 & o & 2 & 8 & $12 \%$ \\
\hline Private & 11 & 5 & 8 & 24 & $37 \%$ \\
\hline Farmers & 1 & o & 3 & 4 & $6 \%$ \\
\hline $\begin{array}{l}\text { Traders (surrounded, among islands, } \\
\text { and sea product ) }\end{array}$ & 1 & 2 & 3 & 4 & $9 \%$ \\
\hline Others & 5 & o & 9 & 14 & $22 \%$ \\
\hline damaged & 1 & o & o & 1 & $2 \%$ \\
\hline Total & 29 & 11 & 25 & 65 & $100 \%$ \\
\hline \multicolumn{6}{|l|}{ Monthly payment of the household } \\
\hline Less than 1 million & 17 & 3 & 15 & 35 & $54 \%$ \\
\hline 1-5 million & 12 & 8 & 9 & 29 & $45 \%$ \\
\hline 5-10 million & o & o & 1 & 1 & $2 \%$ \\
\hline More than $10 \mathrm{M}$ million & o & o & o & o & o\% \\
\hline Total & 29 & 11 & 25 & 65 & $100 \%$ \\
\hline \multicolumn{6}{|l|}{ The total number of house owners } \\
\hline 2 people & 3 & 2 & 2 & 7 & $11 \%$ \\
\hline 3 people & 9 & 1 & 5 & 15 & $23 \%$ \\
\hline 4 people & 6 & 1 & 8 & 15 & $23 \%$ \\
\hline 5 people & 6 & 5 & 1 & 12 & $18 \%$ \\
\hline 6 people & 1 & 2 & 4 & 7 & $11 \%$ \\
\hline More than 6 people & 3 & o & 5 & 8 & $12 \%$ \\
\hline No answer & 1 & o & o & 1 & $2 \%$ \\
\hline Total & 29 & 11 & 25 & 65 & $100 \%$ \\
\hline \multicolumn{6}{|l|}{ Drinking Water resources for family } \\
\hline Self-resource & 2 & 1 & o & 3 & $5 \%$ \\
\hline Communal well & 1 & o & 1 & 2 & $3 \%$ \\
\hline $\mathrm{PAM} / \mathrm{RO}$ & 12 & 9 & 15 & 36 & $55 \%$ \\
\hline Saved Rainwater & 2 & o & o & 2 & $3 \%$ \\
\hline Refill of drinking water & 11 & o & 8 & 19 & $29 \%$ \\
\hline No answer & 1 & o & o & 1 & $2 \%$ \\
\hline Broken & o & 1 & 1 & 2 & $3 \%$ \\
\hline Total & 29 & 11 & 25 & 65 & $100 \%$ \\
\hline \multicolumn{6}{|c|}{ Water resources for bathing and washing } \\
\hline Self well & 18 & 11 & 18 & 47 & $72 \%$ \\
\hline Communal well & 8 & o & 6 & 14 & $22 \%$ \\
\hline $\mathrm{PAM} / \mathrm{RO}$ & 1 & o & 1 & 2 & $3 \%$ \\
\hline Saved Rainwater & 1 & o & o & 1 & $2 \%$ \\
\hline No answer & 1 & $\mathrm{o}$ & & 1 & $2 \%$ \\
\hline total & 29 & 11 & 25 & 65 & $100 \%$ \\
\hline
\end{tabular}


from abroad who come to the three Gili who then build cooperation with the local people to develop the business, especially the hotel and restaurant business. Initially, residents of the three Gilis work as fishermen and while farmers. The waters around Gili give good catches while most of the land in Gili is fertile because it is from volcanic material.

Table 1 shows that the people in three Gili choose a relatively expensive technology, which use water reverse osmosis (RO) to meet the needs of fresh water daily. Whereas for the purposes of bathing, washing and toilet (MCK), they have their own wells. The DHL value of water wells (monitoring 20122013) reached $7000 \mu \mathrm{S} / \mathrm{cm}$. At the time of the study, a well located approximately 500 $\mathrm{m}$ from the eastern coastline of Gili Trawangan was found to have EC value of less than $1000 \mu \mathrm{S} / \mathrm{cm}$. One household in the three islands generally consist of 3-4 people. Educational facilities which are available in the village of Gili Indah are an elementary school and a junior high school in Gili Air; an elementary school, a junior high school and a vocational school in Gili Trawangan and one elementary school in Gili Meno.

Type the main occupation of small island communities in North Lombok district and Kepulauan Seribu Islands is different, although both districts are tourist areas. Most of the small island communities in North Lombok regency work as self-employed, while in Kepulauan Seribu, people generally work as fishermen. This is proven by the value of $\mathrm{Ho}<0.05$ in column occupation in table 5. It seems that the small island community in Kepulauan Seribu cannot solely rely on tourism sector, so that the fishing profession is still occupied. Tourism in three Gili islands is developed along with the Senggigi tourist developments in the region with local and foreign tourists visiting the country. Kepulauan Seribu generally accepts the new local tourists which increase since 2012.

Both districts have equality in the average number of people's income per month (less than 1 million) and the number of occupants per household (Table 5). The number of people with income of 1-5 million in
North Lombok regency is much higher than the population in Kepulauan Seribu Regency (Yoganingrum et al. 2012). If it is associated with the origin of tourists, it can be said that the people who come to three Gili islands are mainly foreign tourists, while in Kepulauan Seribu, they are almost entirely domestic tourists. The origin of tourists who comes is supposed to influence the amount of income of the community. If it is related to the number of occupants in the same household, it can be said that being residents of the small island in Gili is more prosperous.

In the aspect of drinking water sources of the two districts, they have difference (Ho> 0.05). Allegedly, because the people in North Lombok regency are relatively more prosperous, they tend to choose sources of drinking water which is more expensive. $\mathrm{RO}$ technology is expensive because the membranes are easily damaged due to heavy work, especially if the water is getting salty processed or contain a lot of waste. RO technology should be applied to areas that are in need, for example, tourist areas or islands with the increasing economic capacity of the population. Although using RO water, people should still maintain the quality of the environment of the island, so that processed well water does not become salty. Increased awareness and ability to use RO technology is done with appropriate information services.

The consumption of fresh water at Gili islands is higher than in Kepulauan Seribu. The quantity and quality of fresh water will decrease rapidly. This higher consumption is due to the high number and duration of tourists visiting Gili islands while in Kepulauan Seribu it is only consumed by local people. The geological structures in Gili islands allow increased storage capacity of fresh water in the volcanic rock layers. This can be done in a number of ways that multiply the absorption wells to reduce the flow of rainwater into the sea, waste water treatment and then dispose it on land instead of at seas well as the injection of rainwater on layers of freshwater aquifers which have been depleted and replaced by seawater breaks into or through infiltration wells. 


\section{Understanding and behavior of the population}

Table 2 presents the public understanding of freshwater, the issue of global warming and sanitation. While Table 3 presents the behavior of people towards fresh water and waste. In both tables, the first answer is the most appropriate, while the answer to the second and so on are getting less precise answer.

In Table 2, it appears that in general, the small island community in North Lombok district chooses a second or third answer. It shows lack of understanding on the aspects of freshwater, global warming and sanitation. Most people in the population $(52 \%)$ do not know why the original fresh well water is too salty or not salty, and most of them (37\%) choose the condition of land / geology of the island as the cause shortages of fresh water in the three Gili islands. About the understanding of global warming, $43 \%$ of respondents choose the answer of strong, large and long as waves the cause of the erosion at the beach. As many as $37 \%$ of respondents have heard the term of global warming but do not understand the point, and $34 \%$ of respondents answer that they have not heard about it at all. In the next question, $58 \%$ of respondents do not know the consequences of global warming. In this section, $18 \%$ of questionnaires were declared as damaged because the way of answer that does not follow the instructions (circled all).

People's understanding of freshwater, global warming and sanitation needs to be improved so that they can maintain and protect the environment better. The increased understanding will improve disaster mitigation and adaptation to the effects of global warming. Increased understanding can be done with the content and the dissemination of information to the appropriate media.

In Table 3, most respondents apparently choose the first answer. It shows that the community has had good behavior in using the fresh water and sanitation. A total of $69 \%$ of the population have a good behavior in the use of daily fresh water, which is just enough for domestic use. As many as $71 \%$ of respondents are admitted to dispose their domestic wastewater into an open ditch in the yard or dump it to the ground. Most respondents (85\%) have used a latrine with a septic tank. Respondents who throw garbage by burning / planting / asking the help from officer are as many as $78 \%$. And $54 \%$ of respondents answer that the seepage of septic tanks and wastewater / solid waste is the cause of groundwater to stink and as many as $34 \%$ do not know.

People's behaviors in disposing the liquid household waste and the type of latrines in both districts are different (Table 5). Most of the small island communities in Kepulauan Seribu district dispose of liquid household waste into the sea, while the second largest group throws into a ditch in the yard (Yoganingrum et al. 2012). And small island communities in North Lombok regency generally throw into a ditch in the yard and a number of respondents process them first before being disposed. Similarly on the type of latrines in both districts, although most people in Kepulauan Seribu have septic tanks, but the number of people who use the sea as a toilet is high enough (Yoganingrum et al. 2012). While in North Lombok, in general households have septic tanks and only a small percentage of people who use the sea as a toilet. The behavior of a small island community in North Lombok district can be said better. It may be related to a better household income for building a septic tank. In addition it is also related to the dominance of foreign tourists who come to visit the region, where foreign tourist demand for higher environmental cleanliness. Besides, the characteristic aspects of the island-forming rock may also influence the results of the questionnaire. Manufacture of septic tank depends on groundwater levels, where the coral reefs of the island such as Kepulauan Seribu cluster is difficult to be done. The use of septic tanks is easy to do in a cluster of Gili in Lombok because the land is higher $2 \mathrm{~m}$ and is made of volcanic sand material. In the case of Panggang island in Kepulauan Seribu region, it is suspected that there is no available land to build septic 
Table 2. People's Understanding

\begin{tabular}{|c|c|c|c|c|c|c|}
\hline & \multirow{2}{*}{ Knowledge } & \multicolumn{3}{|c|}{ Gili Islands } & \multicolumn{2}{|c|}{ Analysis } \\
\hline & & Air & Meno & Trawangan & Total & Percentage \\
\hline \multicolumn{7}{|c|}{ The causing factor of eroded beach } \\
\hline 1 & $\begin{array}{l}\text { There is no coral and mangrove as } \\
\text { wave destroyer }\end{array}$ & 7 & 3 & 8 & 18 & $28 \%$ \\
\hline 2 & $\begin{array}{l}\text { Strong wave, continuous and } \\
\text { long, besides lacking of sand and } \\
\text { dust }\end{array}$ & 15 & 2 & 11 & 28 & $43 \%$ \\
\hline 3 & Don't know & 5 & 6 & 6 & 17 & $26 \%$ \\
\hline 4 & Others & 1 & o & o & 1 & $2 \%$ \\
\hline & Damaged & 1 & o & $\mathrm{o}$ & 1 & $2 \%$ \\
\hline & & 29 & 11 & 25 & 65 & $100 \%$ \\
\hline \multicolumn{7}{|c|}{ Terms on Global Warming } \\
\hline 1 & $\begin{array}{l}\text { Have heard and understood the } \\
\text { meaning }\end{array}$ & 10 & o & 7 & 17 & $26 \%$ \\
\hline 2 & $\begin{array}{l}\text { Have heard and did not under- } \\
\text { stand the meaning }\end{array}$ & 9 & 7 & 8 & 24 & $37 \%$ \\
\hline 3 & Never heard & 8 & 4 & 10 & 22 & $34 \%$ \\
\hline 4 & No answer & 1 & o & o & 1 & $2 \%$ \\
\hline & Damaged & 1 & o & $\mathrm{o}$ & 1 & $2 \%$ \\
\hline & al & 29 & 11 & 25 & 65 & $100 \%$ \\
\hline \multicolumn{7}{|c|}{ The Consequences of Global Warming } \\
\hline 1 & $\begin{array}{l}\text { Fresh water turns into salt water } \\
\text { because of sea water }\end{array}$ & 4 & o & 3 & 7 & $11 \%$ \\
\hline 2 & Dried well & 1 & 1 & 4 & 6 & $9 \%$ \\
\hline 3 & Don't know & 11 & 10 & 17 & 38 & $58 \%$ \\
\hline 4 & No answer & 2 & o & o & 2 & $3 \%$ \\
\hline & Damaged & 11 & o & 1 & 12 & $18 \%$ \\
\hline & & 29 & 11 & 25 & 65 & $100 \%$ \\
\hline \multicolumn{7}{|c|}{ The causing factors of well water becomes salty } \\
\hline 1 & $\begin{array}{l}\text { Excessive exploitation of well wa- } \\
\text { ter }\end{array}$ & 7 & o & 2 & 9 & $14 \%$ \\
\hline 2 & Long dry season & 4 & o & 7 & 11 & $17 \%$ \\
\hline 3 & Don't know & 10 & 8 & 16 & 34 & $52 \%$ \\
\hline 4 & No answer & 6 & 3 & o & 9 & $14 \%$ \\
\hline & Damaged & 2 & o & $\mathrm{O}$ & 2 & $3 \%$ \\
\hline & & 29 & 11 & 25 & 65 & $100 \%$ \\
\hline \multicolumn{7}{|c|}{ The causing of an island to be lack of fresh water } \\
\hline$\overline{1}$ & $\begin{array}{l}\text { The geological condition of the } \\
\text { land }\end{array}$ & 15 & 1 & 8 & 24 & $37 \%$ \\
\hline 2 & Lack of vegetation & 5 & 1 & 9 & 15 & $23 \%$ \\
\hline 3 & Long dry season & 6 & 7 & 7 & 20 & $31 \%$ \\
\hline & No answer & 3 & 2 & 1 & 6 & $9 \%$ \\
\hline & & 29 & 11 & 25 & 65 & $100 \%$ \\
\hline \multicolumn{7}{|c|}{ The causing factor of smelly ground water } \\
\hline$\overline{1}$ & $\begin{array}{l}\text { Pollution from septic tank or liq- } \\
\text { uid/solid waste }\end{array}$ & 15 & 5 & 15 & 35 & $54 \%$ \\
\hline 2 & $\begin{array}{l}\text { Pollution from sea/well water of } \\
\text { wetland }\end{array}$ & 4 & 0 & 1 & 5 & $8 \%$ \\
\hline 3 & Don't know & 7 & 6 & 9 & 22 & $34 \%$ \\
\hline & No answer & 3 & $\underline{0}$ & o & 3 & $5 \%$ \\
\hline & & 29 & 11 & 25 & 65 & $100 \%$ \\
\hline
\end{tabular}


Table 3. People's Behavior

\begin{tabular}{|c|c|c|c|c|c|}
\hline \multirow{2}{*}{ Behavior } & \multicolumn{3}{|c|}{ Gili Islands } & \multicolumn{2}{|c|}{ Analysis } \\
\hline & Air & Meno & Trawangan & Total & Percentage \\
\hline \multicolumn{6}{|l|}{ The way of using fresh water daily } \\
\hline $1 \quad$ Just enough for household needs & 18 & 9 & 18 & 45 & $69 \%$ \\
\hline 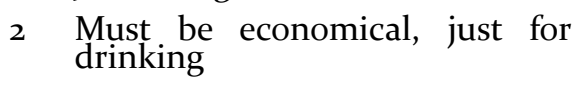 & 4 & 2 & 7 & 13 & $20 \%$ \\
\hline 3 It is okay, as much as possible & 4 & o & o & 4 & $6 \%$ \\
\hline 4 No answer & 2 & o & o & 2 & $3 \%$ \\
\hline $5 \quad$ Damaged & 1 & $\mathrm{O}$ & $\mathrm{O}$ & 1 & $2 \%$ \\
\hline Total & 29 & 11 & 25 & 65 & $100 \%$ \\
\hline \multicolumn{6}{|c|}{ The way of disposing the liquid waste (residue from showering, dish washing, etc) } \\
\hline $1 \quad \begin{array}{l}\text { Processed it in the bucket the wa- } \\
\text { ter is disposed }\end{array}$ & 5 & 2 & 8 & 15 & $23 \%$ \\
\hline 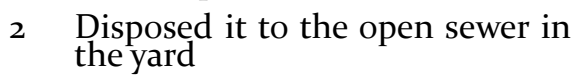 & 22 & 8 & 16 & 46 & $71 \%$ \\
\hline 3 Disposed it to the sea directly & o & o & o & o & o\% \\
\hline $4 \quad$ No answer & 2 & 1 & 1 & 4 & $6 \%$ \\
\hline Total & 29 & 11 & 25 & 465 & $100 \%$ \\
\hline \multicolumn{6}{|l|}{ Type of latrines } \\
\hline $1 \quad$ latrine with septic tank & 25 & 8 & 22 & 55 & $85 \%$ \\
\hline $2 \begin{array}{l}\text { latrine is processed through a } \\
\text { non-septic tank system }\end{array}$ & 2 & 3 & 3 & 8 & $12 \%$ \\
\hline 3 latrine above the sea & 1 & o & o & 1 & $2 \%$ \\
\hline $4 \quad$ No answer & 1 & $\mathrm{o}$ & $\mathrm{o}$ & 1 & $2 \%$ \\
\hline Total & 29 & 11 & 25 & 65 & $100 \%$ \\
\hline \multicolumn{6}{|l|}{ Place to dispose the household waste } \\
\hline 1 Burned/buried/processed by of- & 24 & 8 & 19 & 51 & $78 \%$ \\
\hline 2 Disposed to unofficial sewer/bin & 2 & 2 & 6 & 10 & $15 \%$ \\
\hline 3 Disposed to the sea & o & o & o & o & o\% \\
\hline $4 \quad$ No answer & 3 & 1 & $\mathrm{O}$ & 4 & $6 \%$ \\
\hline Total & 29 & 11 & 25 & 65 & $100 \%$ \\
\hline
\end{tabular}

tanks because the density of the buildings on the island. Conditions on the island stage can also occur in other densely populated islands.

\section{Media information of society choice}

Based on the data in Table 4, 31\% of respondents choose the delivery of information carried by officers who come and talk to the people, while $29 \%$ of people want information delivered through the mosque. Meanwhile $43 \%$ of the population have televisions at home and $36 \%$ use mobile phones. The television programs which are preferred are news (39\%) and film / sitcom / drama (27\%). As many as $45 \%$ of respondents choose village /district heads as a place to find information about fresh water / sanitation. 19\% choose the answer "others" and do not give specific answers. While $12 \%$ will ask their neighbors, and $12 \%$ call the relevant agencies.

Small island communities in the two districts have equality in the selection of information delivery through the clerk, television and mosques. It shows that people prefer information presented orally. Based on community assessment, the relevant officers are the most appropriate to deliver information to citizens, supporting the finding of Meyer (2005) that the success of the provision of information depends on the provider's ability to communicate with the public.

Only a small proportion of small island communities in North Lombok district and Kepulauan Seribu choose radio as a medium of information. These data support 
Table 4. Media information which is wanted by the public

\begin{tabular}{|c|c|c|c|c|c|c|}
\hline & \multirow{2}{*}{ Information Media } & \multicolumn{3}{|c|}{ Gili Islands } & \multicolumn{2}{|c|}{ Analysis } \\
\hline & & Air & Meno & Trawangan & Total & Percentage \\
\hline \multicolumn{7}{|c|}{ Information Channel/media preference } \\
\hline 1 & Radio & 3 & o & 3 & 6 & $5 \%$ \\
\hline 2 & Mosque & 16 & 3 & 15 & 34 & $29 \%$ \\
\hline 3 & Brochure & 4 & o & 8 & 12 & $10 \%$ \\
\hline 4 & TV & 9 & 6 & 3 & 18 & 16 \\
\hline 5 & Officer come and talk to people & 19 & 1 & 16 & 36 & $31 \%$ \\
\hline 6 & Newspaper & 2 & o & 1 & 3 & $3 \%$ \\
\hline 7 & Others & 3 & o & 4 & 7 & $6 \%$ \\
\hline 8 & No answer & 2 & 2 & o & 4 & $3 \%$ \\
\hline \multicolumn{2}{|c|}{ Total } & 58 & 12 & 50 & 116 & $100 \%$ \\
\hline \multicolumn{7}{|c|}{ The existing information media and communication at home } \\
\hline 1 & Radio/HT & 7 & $\mathrm{o}$ & 3 & 10 & $9 \%$ \\
\hline 2 & TV & 22 & 8 & 20 & 50 & $43 \%$ \\
\hline 3 & Cell Phone & 21 & 3 & 18 & 42 & $36 \%$ \\
\hline 4 & Telkom Phone & o & 3 & 1 & 4 & $3 \%$ \\
\hline 5 & Internet & 4 & 1 & 1 & 6 & $5 \%$ \\
\hline 6 & Newspaper & 1 & o & 1 & 2 & $2 \%$ \\
\hline 7 & No Answer & 2 & 1 & $\mathrm{o}$ & 3 & $3 \%$ \\
\hline \multicolumn{2}{|c|}{ Total } & 57 & 16 & 44 & 117 & $100 \%$ \\
\hline \multicolumn{7}{|c|}{ The most watched TV Show } \\
\hline 1 & Film/ soup opera /drama & 12 & 7 & 10 & 29 & $27 \%$ \\
\hline 2 & News & 22 & 7 & 12 & 41 & $39 \%$ \\
\hline 3 & Discussion & 13 & o & 3 & 16 & $15 \%$ \\
\hline 4 & Debate & 5 & 1 & 1 & 7 & $7 \%$ \\
\hline 5 & Others & 7 & o & 4 & 11 & $10 \%$ \\
\hline 6 & No Answer & 22 & o & $\mathrm{o}$ & 2 & $2 \%$ \\
\hline & & 61 & 15 & 30 & 206 & $100 \%$ \\
\hline \multicolumn{7}{|c|}{ The place to look for information dealing with problems of fresh water/well and sanitation } \\
\hline 1 & Head of Village/District & 17 & o & 20 & 37 & $44,5 \%$ \\
\hline 2 & Neighbor or public figure & 5 & 3 & 2 & 10 & $12.05 \%$ \\
\hline 3 & Telephone/coming to other & 5 & 2 & 3 & 10 & $12.05 \%$ \\
\hline 4 & In the newspaper & o & o & o & o & o,00o\% \\
\hline 5 & In TV & 1 & o & o & 1 & $1,20 \%$ \\
\hline 6 & Library & o & 3 & 1 & 4 & $4,8 \%$ \\
\hline 7 & $\begin{array}{l}\text { Calling or coming to friends/ } \\
\text { families }\end{array}$ & o & 1 & 1 & 2 & $24,1 \%$ \\
\hline 8 & Others & 10 & 1 & 5 & 16 & $19,28 \%$ \\
\hline & No Answer & 2 & 1 & $\mathrm{O}$ & 3 & $3,61 \%$ \\
\hline \multicolumn{2}{|c|}{ Total } & 40 & 11 & 32 & 83 & $100 \%$ \\
\hline
\end{tabular}

the results of the study in five districts / cities, Indramayu, North Jakarta, Batu, Serdang Bedagai, and Bau-Bau, on the limited number of radio listeners among farmers and fishermen (Hidayati 2012). The number of households owning a radio / radio communications in North Lombok and the Kepulauan Seribu (Yoganingrum et al. 2012) is much less than those who have televisions and mobile phones (cell phones). Television is a medium that is more popular in the countryside. For field farmers and fishermen whose work area can cover radio broadcasts, the tool is easy to carry because of its small size and weatherproof feature. Besides, it requires less power from the battery. This is presumably due to the development of tourism which has changed the main oc- 
Table 5. The two-sample test results

\begin{tabular}{llr}
\hline & \multicolumn{1}{c}{ Criteria } & Kolmogorov-Smirnov \\
\cline { 2 - 3 } Nationality & Occupation & Asymp.sig. (2-tailed) \\
& Income & 0.998 \\
& Population & 0,122 \\
& Drinking water in the sink & $\mathrm{o}$ \\
\hline Knowledge & The cause of the beach eroded & $\mathrm{o}$ \\
& Term of global warming & 0.63 \\
& Consequence of water scarcity & $\mathrm{o}$ \\
& The cause of salted water to be & $\mathrm{o}$ \\
& freshwater & \\
& Polluted to fresh water & 0.3444 \\
& The lack of water supply & 0.181 \\
\hline Behavior & The step to use fresh water & 0.092 \\
& The way how to dispose liquid & 0 \\
& household waste & 0.001 \\
& Type of latrines & 0.936 \\
\hline Place to dispose the waste & 0.425 \\
Information & The chosen information media & 0.364 \\
& The available & 0.361 \\
& TV Program which you love. & $\mathrm{o}$ \\
& Place to check the information &
\end{tabular}

cupation of the people of North Lombok, from fishermen into business tourism. Radio was originally relied when people went fishing deeply into the center, replaced by other media, because of the time on land becomes more available. Fishing in Kepulauan Seribu region generally only requires a relatively short time for fishing and the area for fishing is not far from the residence. The efforts to increase the use of radio as a means of information access will be more effectively targeted to communities of fishermen who spend more time at sea or in port, where they live far away from other information media such as television. Abdurrahim (2012) choose radio as a medium to deliver information on climate change to increase the adaptability of farmers and fishermen groups.

It is necessary to consider the use of certain information media, in order to meet groups of people who choose that media information (Chen et al. 2011). It is expected that the information services can reach all levels of society. The use of animation film as a means of disseminating information in the two districts also needs to be considered (Yoganingrum et al. 2012), given the nature of population who like the delivery of information orally and television as a medium of information which is preferred and owned by many households. The strength of an animated film as a medium of information is to have the ability to convey original shape of freshwater management technology and it is easily packaged in a compact disc (CD), making it easy to carry or send. Threedimensional animated film is considered to be able to convey information clearly about natural phenomena, ranging from the formation of a small island to the process of collected fresh water and how to manage it sustainably as well as the threats that could undermine its quality and availability. If it is equipped with a simple introduction to the language, then the animated film will be effective as a medium for the dissemination of information (Yoganingrum et al. 2014). Dolnicar et al (2010) finds if the information related to the utilization of fresh water in the form of images will facilitate the understanding of the presented information. Shepard and Shaw (2007) and Baldwin et al (2012) prove that the information presented in a three-dimensional visualization is capable of attracting the attention of and engaging 
stakeholders in environmental issues.

The places of information search when people find a problem with fresh water on a small island community of North Lombok district and Kepulauan Seribu are different. In terms of percentage, both districts have the same number to search for the head of the village/district (Yoganingrum et al. 2012). However, the two-sample test shows a rejection of the hypothesis (Table 6). Gili island community in North Lombok chooses others as the answer to the second highest answer, but they do not write specifically. Meanwhile, in Kepulauan Seribu area, the second and third highest value is to neighbor/community leaders and telephone/ coming to certain agencies (Yoganingrum et al. 2012). Based on these data, it could be seen that small island communities in North Lombok does not likely to have problems in the availability of fresh water, but if there are problems they will ask the village chief/district. Mainland geology of small islands in North Lombok has a better ability to store rainwater than mainland conditions of Kepulauan Seribu. But this time, the region in the three Gili islands begins to experience a declining water quality due to its excessive use of which triggers saltwater intrusion. Allegedly, the public will begin to require an explanation of what happens to the fresh water damage. Community contact with foreign tourists who have a more open information culture could cause the immergence of such alternative option.

Referring to the aspect of geohydrology, Kepulauan Seribu is built from the coral reefs which have limited ability to store rainwater. Cluster of islands in the North Lombok crusts is formed by volcanic material which has a better ability to absorb and store rainwater. Information on this matter is needed to be conveyed to the public in order to grow awareness of protecting the environment which is important for hydrological cycle. Both regions still keep the possibility of obtaining fresh water in the soil, but it is not recommended for people, because overuse of ground water can lead to sea water intrusion. Management of deep wells should only be performed by the go- vernment for the common good, so that it can be controlled.

\section{CONCLUSION}

Increasing tourism sector, especially the arrival of foreign tourists in coastal areas and small islands can change the main occupation of the people, from professional fishermen into tourist actors. This change in livelihood is followed by an increase in household income per month. Changing the main livelihood and increase household incomes have a positive impact, one of which is the behavior of the community such as building clean septic tanks at household latrines and dispose the domestic wastewater into the sewer even processing them before disposing it. It also affects the choice of technology for the supply of drinking water. People in Gili island are more prosperous in selecting $\mathrm{RO}$ technology which is more expensive to procure a source of drinking water.

The rapid rise of tourism activities in the three Gili islands increases the consumption of fresh water taken from the shallow aquifer. The result is a decline in the quality of fresh water into the salty due to sea water intrusion. The increase in population in Kepulauan Seribu is also followed by an increase in the consumption of fresh water, although not as big as in Gili islands. Geological conditions of the coral reef islands in Kepulauan Seribu accelerate the entry of sea water into the aquifer. Considering that geological structure of the small island in Kepulauan Seribu, people are difficult to build a septic tank. Therefore, the need to find a way out to prevent people not to make the sea as a toilet is very urgent.

In general, coastal communities and small islands in both districts prefer information presented orally by the authorized officers. Packaging information conveyed orally as animated films needs to be considered in both districts.

\section{ACKNOWLEDGMENT}

Biggest gratitude addressed to Dr. Sigit Anggoro Putro Dwiono from oceanology LIPI Research Center who helped spreading the 
questionnaire on the island of Gili Meno.

\section{REFERENCES}

Abdurrahim, A.Y., 2012. Radio sebagai media sosialisasi perubahan iklim. Dalam buku Perubahan iklim: Upaya peningkatan pengetahuan dan adaptasi petani dan nelayan melalui radio. Sarana Komunikasi Utama, Bogor.

Amiruddin, S., 2014. Jaringan sosial pemasaran pada komunitas nelayan tradisional Banten. Jurnal Komunitas, 6(1), pp.106-115.

Baldwin, C., et al., 2012. How scientific knowledge informs community understanding of groundwater. Journal of Hydrology, 474, pp.74-83

Bryana, E., et al., 2009. Adaptation to climate change in Ethiopia and South Africa: options and constraints. Environmental Science E Policy, 12(4), pp.413-426.

Dolnicar, S., et al., 2010. The effect of information on public acceptance: The case of water from alternative sources. Journal of Environmental Management, 91, pp.1288-1293

Gentle, P. and Maraseni, T.N., 2012. Climate change, poverty and livelihoods: adaptation practices by rural mountain communities in Nepal. Environmental science E policy, (21), pp.24-34

Harini, N.D., 2012. Dari Miyang ke Longlenan: Pengaruh jaringan sosial pada transformasi masyarakat nelayan. Jurnal Komunitas, 4(2), pp.178-19o

Hantoro. W.S., et al., 2008a. Perubahan muka air laut global di Indonesia: ancaman bencana bagi wilayah pesisir dan pulau kecil. Buku Kumpulan naskah Kenaikan Muka laut Relaatif dan Kerentanan Wilayah Pesisir dan pulau-pulau kecil di Indonesia. Pusat Riset Wilayah Laut dan Sumberdaya Nonhayati. BRKP-DKP, Jakarta.

Hantoro. W.S., et al., 20o8b. Air Tawar di Pulau Kecil Terumbu Karang Derawan di Kalimantan Timur: Contoh Masalah dan Antisipasi Terhadap kenaikan muka laut Global. Buku Kumpulan naskah Kenaikan Muka laut Relaatif dan Kerentanan Wilayah Pesisir dan pulau-pulau kecil di Indonesia. Pusat Riset Wilayah Laut dan Sumberdaya Nonhayati. BRKP-DKP, Jakarta.

Hantoro W.S., 2010. Kawasan Pesisir dan Pulau Kecil landai di Indonesia: Pengelolaan SD Air dan lingkungan berbasis daya dukung ekosistim serta mitigasi - adaptasi terhadap keadaan dan kejadian ekstrem alamiah dan dampak antro- pogen. Prosiding Pertemuan Himpunan Ahli Hidrologi Indonesia, August 2010, Ambon.

Hantoro W.S., et al., 2013. Kerentanan pesisir pulau kecil landai Kepulauan Aru terhadap muka laut tinggi kejadian ekstrem. Puslit Geoteknologi LIPI, Bandung.

Hantoro W.S., et al., 2014. Mitigasi, adaptasi dan peningkatan ketahanan sumber daya alam serta lingkungan terhadap kondisi ekstrem atau bencana dampak gangguan iklim (slow/ rapid onset) di kawasan pesisir dan pulau kecil wilayah perbatasan (Kepulauan Aru): adaptasi dan penguatan neraca air tawar. Puslit Geoteknologi LIPI, Bandung.

Hidayati, D. 2012. Peran radio dalam peningkatan pemahaman petani dan nelayan terhadap perubahan iklim. Dalam buku Perubahan iklim: Upaya peningkatan dan adaptasi petani dan nelayan melalui radio. Sarana Komunikasi Utama, Bogor.

Meyer, H.W.J., 2005. The nature of information, and the effective use of information in rural development. Information Research 10. http:// informationr.net/ir/10-2/paper214.html. Accessed date 30/06/2012.

Nisbet, M.C and Myers, T. 2007. The Polls-Trends: Twenty Years Of Public Opinion About Global Warming. Public Opinion Quarterly, 71(3), pp.444-470

Sheppard, S.R.J, et al. 2011. Future visioning of local climate change: A framework for community engagement and planning with scenarios and visualization. Futures, 43(4), pp.400-412.

Zach, L. and McKnight, Michelynn. 2010. Innovative Services Improvised During Disasters: Evidence-Based Education Modules to prepare student and practitioners for shift in community information needs. Journal of Education for Library and Information Science, 51(2), pp.76-85.

Yoganingrum, A., et al., 2014 Media informasi teknologi pengelolaan air tawar untuk masyarakat pesisir dan pulau kecil di kabupaten kepulauan seribu. in Lokakarya Nasional Dokumentasi dan Informasi: Pengelolaan data dan informasi dalam perkembangan teknologi informasi di era big data.

Yoganingrum, A., Maryati, I., Rezaldi, M.Y. 2012. Kebutuhan dan media informasi pengelolaan air tawar masyarakat di Kepulauan Seribu. IPTEKKOM, 14(2), pp.1410-3346. 